\title{
Influence and Power: The Types of Authority in the Process of Scripturalization
}

\section{Francis Borchardt}

To cite this article: Francis Borchardt (2015) Influence and Power: The Types of Authority in the Process of Scripturalization, Scandinavian Journal of the Old Testament, 29:2, 182-196, DOI: 10.1080/09018328.2015.1039825

To link to this article: http://dx.doi.org/10.1080/09018328.2015.1039825

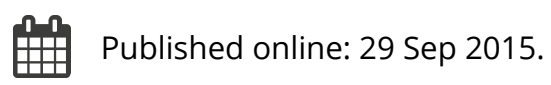

Submit your article to this journal

Q View related articles $\sqsubset$

View Crossmark data $\nearrow$ 


\title{
Influence and Power: The Types of Authority in the Process of Scripturalization
}

\author{
Francis Borchardt \\ Lutheran Theological Seminary Hong Kong \\ 50 Tao Fung Shan Rd., Shatin, N.T. Hong Kong SAR, China \\ $+85293761537$ \\ archaeology@gmail.com
}

\begin{abstract}
Many scholars recognize the importance of authority in the process of scripturalization. The presence of words like "authority" and "authoritative" in definitions of the term "scripture" is ubiquitous. Many also identify authoritative status for a text as an important step on the way toward it becoming scripture. However, "authority" and the words that derived from it are ill-defined in most studies. Even when the term and its synonyms are defined, there is little empirical evidence for the type of reception described. Further, there is hardly any recognition of the various ways in which a text can be seen as authoritative (historically accurate, politically expedient, divinely inspired, etc.). This paper attempts to fill this gap in our knowledge by looking to ancient testimonies, which explicitly describe the reception of texts in order to discern the varieties of ways a text might be recognized as a notable source.
\end{abstract}

Key words: Canon, 2 Maccabees, Sirach, Letter of Aristeas, Scriptural Reception

\section{Introduction}

When discussing the production, transmission, and reception history of parascriptural ${ }^{1}$ texts, there is no more fundamental concept than "authority". The term is found throughout definitions of scripture from all quarters. "Scripture" is sometimes described as a species of the genus of authoritative literature. $^{2}$ Alternatively, it can be characterized as literature that has achieved

1. I use this term in the sense described by Robert A. Kraft in his SBL presidential address "Paramania: Beside, Before and Beyond Biblical Studies," JBL 126 (2007), pp. 5-27, at p. 9, referring to the literature that provides the context for and thereby helps to define what is considered to be scripture.

2. See e.g. A.C. Sundberg, The Old Testament of the Early Church (Cambridge, Mass.: Harvard University Press, 1964), who defines scripture as literature perceived as both holy and authoritative. He is followed conceptually by Eugene Ulrich "The Notion and Definition of Canon," in The Canon Debate (ed. Lee Martin McDonald 
especially high authority. ${ }^{3}$ Other definitions will treat scripture and authoritative literature as basically synonymous. ${ }^{4}$ Two deductions are obvious from a brief survey of this literature: 1) parascripture bears some relationship to authority, and 2) there is a dearth of clarity concerning this relationship. I have a suspicion that this vagueness arises from a failure to accurately describe the contours and sources of authority in literature.

There are several steps one can take to solve this problem. The first step, which may be helpful is to look at dictionary definitions and etymologies of the word. The Oxford English Dictionary notes that the English word authority derives from Latin auctoritas by way of the French autorité and possesses, among other senses, the meaning: "power to influence action, opinion, belief." When applied to literature "authority" is defined as "the quotation or book acknowledged, or alleged, to settle a question of opinion or give conclusive testimony." ized concepts biblical scholars are attempting to express with our use of the term. We want to know, after all, how parascriptural texts were treated as they moved from the stage of being published to becoming influential works. This definition points out the fact that a text becomes an authority once it is acknowledged or alleged to have the power to influence action, opinion, or belief. It points our focus in the direction of empirical use of texts, and also serves as a reminder that the threshold for being recognized as an authoritative work ought not to be set too high. However, the dictionary does not provide us with real examples of such usage.

and James A. Sanders; Peabody, Mass.: Hendrickson, 2002), pp. 21-35, esp. p. 29. Here Ulrich notes that scripture is distinguished from other authoritative literature in that is considered to be sacred, divinely authored (or inspired?), and eternally and universally applicable by a given group.

3. See e.g. James Vanderkam, "Authoritative Literature in the Dead Sea Scrolls," DSD 5 (1998), pp. 382-402, esp. pp. 382, 389, 392. Similarly, Robert A. Kraft "Finding Adequate Terminology for 'Pre-Canonical' Literatures," n.p. [cited 17 July, 2013] Online: http://ccat.sas.upenn.edu/rak/SBL2007/canon/

4. See e.g. Peter W. Flint, "Noncanonical Writings in the Dead Sea Scrolls: Apocrypha, Other Previously Known Writings, Pseudepigrapha” in Peter W. Flint (ed), The Bible at Qumran: Text, Shape, and Interpretation (Grand Rapids, Mich.: William B. Eerdmans, 2001), 80-123, esp. 116-121. Also, Roger Beckwith, "Formation of the Hebrew Bible," in Martin Jan Mulder and Harry Sysling (eds), Mikra: Text, Translation, Reading and Interpretation of the Hebrew Bible in Ancient Judaism and Early Christianity (CRINT, 2/1; Assen: Van Gorcum, 1988; repr. Peabody, Mass.: Hendrickson, 2004), pp. 39-86, esp. p. 46.

5. "authority, n.”. OED Online. June 2013. Oxford University Press. 18 July 2013 $<$ http://www.oed.com.libproxy.helsinki.fi/view/Entry/13349? redirectedFrom=authori ty>

6. Ibid. This sense and that noted above in n.5 appear to carry through to Latin usage: "auctōrìtas." Charlton T. Lewis; Charles Short [1879], A Latin Dictionary; Founded on Andrews' edition of Freund's Latin dictionary (Trustees of Tufts University, Oxford). 18 July 2013 http://perseus.uchicago.edu/cgibin/philologic/getobject.pl?c.0: 4424.lewisandshort. 
Further investigation is called for. An empirical study of how texts seek authority from their audiences is a method frequently employed by scholars. ${ }^{7}$ These studies can illuminate how an author ${ }^{8}$ seems to use certain literary techniques or rhetorical flourishes to lend credibility and gravity to a text. These types of investigations only illustrate part of the picture, however. Authority, after all, is a matter of reception. ${ }^{9}$ It is granted by an audience to an individual or text, sometimes willingly, but often through coercion. Only observing the strategies an author seems to use to attain authority does not actually reveal how or why the authority was granted. There is no way to tell whether Daniel, for example, was accepted by a given group as authoritative simply by observing that its authors used pseudepigraphy or the prospect of divine revelation when composing the material. Though the findings of such studies are an undoubtedly important part of the picture, and are of the highest importance for literary analysis, they must be buttressed. In order to discern how authority was actually granted by audiences we must concentrate instead, on the reception of parascriptures.

My aim in this paper is to describe and examine the reasons provided for recognizing a text as authoritative by $2^{\text {nd }}$ century $\mathrm{BCE}$ authors. I intend to demonstrate that because authority is unique to reception communities, and manifests itself so differently in the various ancient witnesses, we must be circumspect of any attempt to aggregate the ideas about the authority of a specific text in multiple contexts. I have chosen $2^{\text {nd }}$ century BCE texts primarily because this has been argued by several scholars to be a time of great clarification concerning which writings became authorities, and alternatively which texts lost the power to influence actions, opinions, and beliefs. ${ }^{10}$ The texts which I will primarily discuss are the Letter of Aristeas, ${ }^{11}$ the second

7. See e.g. Hindy Najman, Seconding Sinai: The Development of Mosaic Discourse in Second Temple Judaism (JSJSup, 77; Leiden: Brill, 2003); Bernard M. Levinson, Deuteronomy and the Hermeneutics of Legal Innovation (Oxford: Oxford, 1997).

8 Here and throughout the article used as shorthand for any number of complex models of composition.

9 Molly M. Zahn, "Talking about Rewritten Texts: Some Reflections on Terminology" in Hanne Von Weissenberg, Juha Pakkala, and Marko Marttila (eds), Changes in Scripture: Rewriting and Interpreting Authoritative Traditions in the Second Temple Period (BZAW 419; Berlin: De Gruyter, 2011), pp. 93-119, esp. p. 99.

10. Roger Beckwith, The Old Testament Canon of the New Testament Church and Its Background in Early Judaism (Grand Rapids, Mich.: Eerdmans, 1985), pp. 111-165; John J. Collins, "Changing Scripture" in Hanne Von Weissenberg, Juha Pakkala, and Marko Marttila (eds), Changes in Scripture: Rewriting and Interpreting Authoritative Traditions in the Second Temple Period (BZAW, 419; Berlin: De Gruyter, 2011), pp. 23-45, esp. p. 29; David M. Carr, Writing on the Tablet of the Heart: Origins of Scripture in Literature (Oxford: Oxford University Press, 2005), p. 262. Each of these scholars, however, has a different emphasis.

11. On the dating of Aristeas to the 2nd century BCE see Elias Bickermann, "Zur Datierung des Pseudo-Aristeas," ZNW 29 (1930), pp. 280-298. 
letter prefixed to 2 Maccabees, ${ }^{12}$ and the translator's prologue to the book of Sirach. ${ }^{13}$ I am not here going to rely on citation formulae, frequency of quotation, or allusions to texts to demonstrate authority. Though all of those can be illustrative, they may be misleading. Debate surrounds the significance of such terms as $\gamma \varepsilon \dot{\gamma} \rho \alpha \pi \tau \alpha$ and כאשר כתב quoted, or even its absence could just as well speak to a text's applicability to a particular situation, or even availability, as it does to the importance of a text. Further, if it indicates anything of use, it is the relative importance instead of absolute value. Allusions to texts are a poor proof of authority because they neither identify their source nor often do they provide any overt indication of status. It thus falls to the biblical scholar to decide whether something is a textual allusion (and to which text!) ${ }^{15}$ and what intent the author had in making this reference. ${ }^{16}$ This is fine material for a theoretical discussion, but not so for empirical research.

I will operate on the principle that if a text or category of texts is mentioned by name and singled out for special status, it is authoritative, at least for the author of the work who mentions it, and possibly also for the author's intended audience. This meets the rather low threshold of "acknowledged or alleged [power] to settle an opinion or give conclusive testimony" set by the definition I offered above. ${ }^{17}$ In each of the examples I shall cite the author in fact does both. He or she both acknowledges the book mentioned as an authority and alleges it is an authority for the audience. The final piece of the puzzle, however remains. We cannot know whether those who read the Letter of Aristeas, for example, accepted the Old Greek translation of the Pentateuch as authoritative at all, let alone for which of the reasons Aristeas offers, if any of them. This is not a minor problem, as that data would speak to the authority granted by ever larger audiences. However, it is my contention that this evidence suffices for illustrating some of the unique reasons for granting authority to texts, even if there is only one recipient actually recognizing the text's authority.

12. Though 2 Maccabees likely developed in several compositional stages, and most scholars hypothesize that the second letter was the last part to be added, the normal range of dates suggested for the composition fall between $124 \mathrm{BCE}$ and $63 \mathrm{BCE}$. See the discussion in David S. Williams, "Recent Research in 2 Maccabees," CBR 2 (2003), pp. 69-83, esp. pp. 71-74.

13. See the brief note on the usual dating of the prologue in Benjamin G. Wright, "Access to the Source: Cicero, Ben Sira, the Septuagint, and Their Audiences," JSJ 34 (2003), pp. 1-27, at p. 12.

14. John Barton, Holy Writings, Sacred Text: The Canon in Early Christianity (Louisville, Kent.: Westminster John Knox, 1997), p. 11.

15. See the discussion in Kraft, "Para-Mania," p. 17, where he notes the important role of testimonia and other excerpt sources.

16 Flint, "Noncanonical," p. 119.

17 See the second page of this paper. 


\section{Empirical Examples}

\subsection{Letter of Aristeas}

It should come as no surprise that the Letter of Aristeas has been explored frequently for solutions to questions of textual authority. ${ }^{18}$ Though debate remains as to the purpose of the work, ${ }^{19}$ it is undeniable that it contains vast amounts of information on the early reception of the translation of the Judean law into Greek. Scholarship in this area has tended to come from scholars who prefer to read the Letter of Aristeas as affirming the authority of the Septuagint, and to focus on the strategies employed by the author to have this authority broadly acknowledged. ${ }^{20}$ These are useful for our purposes, but not precisely what we aim to describe here. Since we are focused on concrete reasons for reception as authority, rather than attempts to gain authority, these are only tangentially related to our aim. For instance, though depicting the foundation of the Septuagint as a new Exodus event, as Honigman and De Crom allege, ${ }^{21}$ might have served as an attempt to authorize the Septuagint, it seems rather unlikely that this is the reason the author of Aristeas thought of the Greek translation as authoritative. Likewise, even as placing the praise of the Judeans and their laws in the person of a Hellenistic court official sets up innumerable ways to authorize the Septuagint, as Wright suggests, ${ }^{22}$ it would seem impossible to argue that the author of the work believed in the authority of the Greek text because he told its story in the voice of a Ptolemaic courtier. These rhetorical flourishes might reflect audience expectations, but we cannot be sure of this. It is not the tactics used to convince the audience that we are interested in, but the reasons for which the author recognizes that authority in the first place, if they can be discerned. It is true that some of the findings of these previous scholars may point toward the author's own reasons for authorizing the Greek translation, but they are not always the same thing.

So, what did the author of Aristeas think of the Judean laws, and how do we discern this? It is our contention that there are instances in the midst of the author's presentation, which though certainly incorporated into a broader

18. Recent Studies include: Benjamin G. Wright "Pseudonymous Authorship and Structures of Authority in the Letter of Aristeas" in Géza G. Xeravits, Tobias Nicklas, Isaac Kalimi (eds), Scriptural Authority in Early Judaism and Ancient Christianity (DCLS, 16; Berlin: De Gruyter, 2013), pp. 43-62; Dries De Crom, "The Letter of Aristeas and the Authority of the Septuagint," JSP 17 (2008), pp. 141-160; Sylvie Honigman, The Septuagint and Homeric Scholarship in Alexandria: A Study in the Narrative of the 'Letter of Aristeas' (London: Routledge, 2003).

19. Sylvie Honigman, "The Narrative Function of the King in the Letter of Aristeas," in Tessa Rajak et al. (eds), Jewish Perspectives on Hellenistic Rulers (Berkeley: University of California Press, 2007), pp. 128-146, at p. 128, notes that some scholars argue that the text is meant to give an overall presentation of Judaism, while others (including herself) believe it is composed as a charter myth for the Septuagint.

20. Wright, "Pseudonymous," p. 45; De Crom, “Letter," p. 158.

21. De Crom, "Letter," p. 150; Honigman, "Narrative," p. 133.

22. Wright, "Pseudonymous," pp. 60-61. 
strategy of authorizing the Old Greek translation, ${ }^{23}$ are very likely to reflect the personal ideas of the author and even his intended audience. That the king is made to praise the law, Aristeas admire Judean institutions, and the translators be conversant in Hellenistic popular philosophy is indicative of rhetorical strategy. They are unlikely to be the reasons that the author granted authority to the Old Greek, especially if he consciously invented them. ${ }^{24}$ The strategy though, can only be effective insofar as the characters' sentiments reflect those of the author or his intended audience. Especially if Wright is correct in arguing that the purpose of the composition is to raise the Greek translation to equal status with the Hebrew versions of the law, ${ }^{25}$ it follows that any praise for the written law before translation is presumed by the author to be axiomatic. Therefore, I shall focus on several such instances, describing the reasons for acceptance and the sphere of influence of the law.

The most commonly cited reason for the law's authority in the Letter of Aristeas is divine origin. This can be recognized in no less than six passages. The two most emphatic examples come close to the start and end of the work. The idea is introduced by Demetrius of Phaleron, the famous rhetorician and literary critic at the Museion, a character who conspicuously lends credibility to Aristeas' assertion that the Greek translation of the law will be accurately reproduced. ${ }^{26}$ At $\$ 30-31$ Demetrius remarks that the Hebrew text of the law has been carelessly transcribed and no longer represents the original text. ${ }^{27}$ He goes on to state that, because of this fluid transmission history, it is necessary that the text should be made accurate so that it reflects the original written law, which is both philosophical and perfect, because of its divine origin. This characteristic is apparently so influential that it has even inhibited poets and historians from writing about it or even about those who live according to its contents. The law's divine origin, then, is a central reason for its authority. While the wisdom and perfection of the law are certainly important qualities, they derive from heavenly authorship.

The divine origin is the reason this ostensibly first critical edition is necessary. ${ }^{28}$ Were the law not divinely inspired, it is possible that it would not have been essential to create a perfect copy. The divine perfection of the original demands the mortal attempt at perfection of the Greek translation. Though this passage is likely to be part of a strategy intended to assure the audience

23. Francis Borchardt, "The LXX Myth and the Rise of Textual Fixity" JSJ 43 (2012), pp. 1-21, esp. pp. 14-15.

24. Wright, "Pseudonymous," p. 60.

25. Ibid., p. 60.

26. De Crom, "Letter," p. 148.

27. Benjamin G. Wright, Praise Israel for Wisdom and Instruction: Essays on Ben Sira, Wisdom, the Letter of Aristeas and the Septuagint (JSJS 131; Leiden: Brill, 2008), p. 306, has pointed out that the Hebrew text is the sole focus here, and so the proper translation of $\sigma \varepsilon \sigma \eta \dot{\mu} \mu \nu \tau \alpha \mathrm{l}$ in this case must be "transcribe" instead of "translate".

28 Borchardt, "LXX Myth,” pp. 13-14. 
of the attention to quality inherent in the translation project, ${ }^{29}$ it is also probable that the necessity for this strategy is the presumed divine origin of the original written law, regardless of whether that original is reflected in any Hebrew copies.

Toward the close of the letter the importance of the divine authorship of the law is again underlined. Once more it is Demetrius of Phaleron who is made to provide the evidence. In answer to the king's question as to why the law had never been cited by great historians and poets at $\$ 312$, Demetrius responds that the law is holy and comes from God. He further notes that some who have tried to cite the law have been punished by God for their efforts. This is supported by several examples in the following three paragraphs. Theompompus is apparently driven mad by God for attempting to confuse the divine and profane. Theodektes received cataracts in return for his efforts to adapt some of the law into plays. In both cases God provides the cure after the offender desists. The scenarios described are likely to be fictional, but the sentiment behind them would seem to be genuine. Divine authorship provides its excellence and likely, its authority. Wright may be correct to claim that this scene intentionally recalls $\S 177$ (and also $\$ 31$ ) with the intention of completing the bridge from the authority of the original to the authority of the translation. ${ }^{30}$ This does not, however, undermine the scene as evidence of the author's attitude concerning the relationship between divine origin and authority.

The precise mode of authorship is revealed in a number of verses within the section of the letter wherein Eleazar explains some of the finer points of the law to Aristeas (§133-171). There is a human lawgiver, Moses (§144), but he has been especially created by God with special understanding (\$139). This anticipates, in part, Moses' extraordinary talents in De Vita Mosis (1.2025 ), but it should be noted that, according to $\$ 240$ all lawgivers would appear to have the same gift. This particular instance is illuminating in that this divine inspiration is cited as the reason for which even the king should obey laws. Authority and divinity are closely tied for Aristeas.

The application of the law is not specified by $\S 31$. It appears to be authoritative for life in general. People conduct themselves in public according to the scrolls of the law, and have done so for some time. The life they lead is both pure and reverent. Though not explicated here, $\S 139,142-143$, and 168 illustrate that the law governs every part of life. At $\$ 142$ it is said that the laws affect what its followers eat, drink, touch, hear and see. $\$ 168$ insists the decrees of writings direct one's whole life toward justice, and $\$ 139$ makes clear that the statutes of the law form unbreakable barricades and iron walls surrounding its followers. It would seem that these texts, though very likely intended to convince Aristeas' audience of the law's compatibility with popu-

29. Honigman, Septuagint, p. 20.

30. Wright, "Pseudonymous," p. 48. 
lar Hellenistic philosophy, ${ }^{31}$ are reliable indicators of the extent of its authority for the author.

Though there are other qualities cited, such as purity and philosophical nature, it is evident that a belief in divine origin is the primary reason for which the author of Aristeas grants authority to the written law. The various strategies recognized by scholars might be best understood as attempts to transfer the inherent authority due to divine authorship of the original text to the Greek translation. They are meant to overcome the perceived problems in the process of transmission and translation by replicating in human terms the perfection and philosophical nature of the original which derive from divine origin.

\subsection{Maccabees 1:10-2:18}

Despite an extensive set of empirical examples of textual authorization, the second letter prefixed to 2Maccabees has not been seriously investigated for its input on textual authority. Some studies have tended to focus more on the authenticity and provenance of the letter along with its relationship to both the first epistle and the core text of 2Maccabees. ${ }^{32}$ Though these are important issues for reconstructing a precise chronology of reception and for the literary character of 2 Maccabees, they are not of central importance to the question of authority in the letter. It is enough to note that something like a consensus has emerged around the idea that each of the letters and the epitome emerged independently and were tied together later by an editor, probably due to their shared concern for the cleansing of the temple. ${ }^{33}$

In addition to these discussions, there are also those who have studied the text, especially 2,13-15 in search of indications of a Hasmonean or even $\mathrm{Ne}$ hemian canon. ${ }^{34}$ This has some bearing on authority, but it should be clear

31. Victor Tcherikover, "The Ideology of the Letter of Aristeas," HTR 51 (1958), pp. 59-85, esp. pp. 73-74.

32. E.g. Ben Zion Wacholder, "The Letter from Judah Maccabee to Aristobulus. Is 2 Maccabees 1:10b-2:18 Authentic?" HUCA 49 (1978), pp. 89-133, who represents one side, arguing for authenticity, and Elias Bickermann, "Ein jüdischer Festbrief vom Jahre 124 v. Chr. (II Macc. 1:1-9)," ZNW 32 (1933), pp. 233-254, who is representative of the majority, holding the letter to be a later forgery.

33. Williams, "Recent Research," pp. 72-72; Klaus-Dietrich Schunck, Die Quellen des I. und II. Makkabäerbuches (Halle: Max Niemeyer Verlag, 1954), pp. 97-99. See also Malka Zeiger Simkovich, "Greek Influence on the Composition of 2 Maccabees," JSJ 42 (2011), pp. 293-310, esp. pp. 294-295, who argues this is a main focus of the whole composition, and Thomas A. Bergren, "Nehemiah in 2 Maccabees 1:102:18," JSJ 28 (1997), pp. 249-270, esp. pp. 249-250.

34. Armin Lange, "2 Maccabees 2:13-15: Library or Canon?" in Géza Xervits and Jószef Zsellenger (eds), The Books of the Maccabees: History, Theology, Ideology. Papers of the Second International Conference on the Deuterocanonical Books, Pápa, Hungary, 9-11 June, 2005. (JSJS, 118; Leiden: Brill, 2007), pp. 155-167; Stefan Schorch, "The Libraries in 2 Macc 2:13-15, and the Torah as a Public Document in Second Century BC Judaism" in Géza Xervits and Jószef Zsellenger (eds), 
that these are not identical concepts. ${ }^{35}$ Most recently, Armin Lange and Lee McDonald have shown that attempts to find a canon in these verses are misguided. Lange, for his part, has noted that the collection of books cited in Nehemiah and Judas Maccabeus' library resemble the contents of the typical Hellenistic library. He concludes they are likely intended to depict Judas as a Hellenistic king, rather than the contents of a canon. ${ }^{36}$ McDonald has shown that the primary arguments marshaled for 2Maccabees 2,13-15 as evidence of canon formation are anachronistic. ${ }^{37} \mathrm{He}$ shows that the rather vague titles used to describe the contents of Nehemiah and Judas' collections require reading the outcome of the canonical process into earlier periods. McDonald further underlines how dangerous such a method is, considering what we know about the variety of authoritative literature in antiquity.

Though I agree with Lange and McDonald on their assessment of the canonical question regarding 2,13-15, the presence of these titles and others mentioned within the context of the letter, leads me to believe that it may still be useful for investigating the types of authority in ancient literature. Within

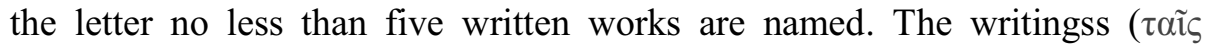

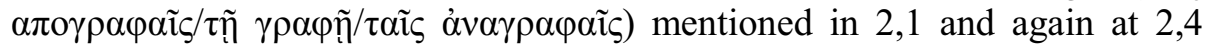
and 2,13 cannot be further specified, but their contents obviously in part describe activity of the prophet Jeremiah, Moses, and Solomon reported in 2,112. It is probable that there is one document among many in the records mentioned here given the singular form in 2,4 . The memoirs of Nehemiah ( $\tau$ oĩ $\varsigma$

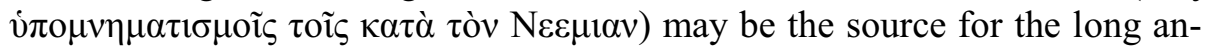
ecdote concerning Nehemiah's dedication of the temple and experience with sacred fire found at 1,18-36. The scrolls concerning kings ( $\tau \dot{\alpha} \pi \varepsilon \rho \grave{i} \tau \tilde{\omega} v$ $\left.\beta \alpha \sigma \lambda \varepsilon_{\varepsilon} \omega v \beta 1 \beta \lambda i \alpha\right)$, the scrolls of the prophets $(\pi \rho \circ \varphi \eta \tau \tilde{\omega} v)$, the scrolls of David ( $\tau \grave{\alpha} \tau o \tilde{v} \Delta \alpha v i \delta$ ), and the letters of kings concerning votive offerings

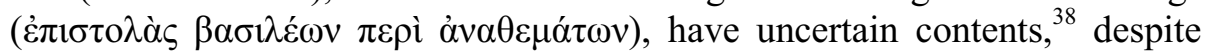
the tendency of the more confident interpreters to assign the titles to well-

The Books of the Maccabees: History, Theology, Ideology. Papers of the Second International Conference on the Deuterocanonical Books, Pápa, Hungary, 9-11 June, 2005 (JSJS, 118; Leiden: Brill, 2007), pp. 169-195; Lee Martin McDonald, The Biblical Canon: Its Origin, Transmission, and Authority (Peabody, Mass.: Hendrickson, 2007); S.Z. Leiman, The Canonization of the Hebrew Scripture: The Talmudic and Midrashic Evidence (Hamden, Conn.: Archon, 1976); Philip R. Davies, "The Jewish Scriptural Canon in Cultural Perspective" in Lee Martin McDonald and James A. Sanders (eds), The Canon Debate (Peabody, Mass.: Hendrickson, 2002), pp. 3652.

35. Ulrich, "Notion," pp. 29-30.

36. Lange, "2 Maccabees," p. 167. He is preceded by Menahem Haran, "Archives, Libraries, and the Order of Biblical Books" JANES 22 (1993), pp. 51-61, esp. p. 59, who notes that Nehemiah is depicted as a Hellenistic king in this passage.

37. McDonald, Biblical, pp. 85-87.

38. Schorch, "Libraries," pp. 170-171. 
known texts. ${ }^{39}$ Yet, they may be of use in the discussion of textual authority. We will treat them in a separate group since their contents are less clear.

The writings containing the story of Jeremiah's activities prior to exile are likely much broader than the anecdotes quoted in 2,1-12. The stories are

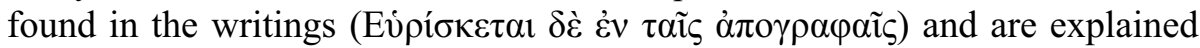

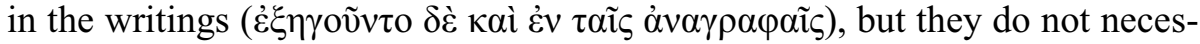
sarily comprise the writings. In fact, there is a reference to a single document at 2,4, which might contain all these anecdotes about Jeremiah, but also likely many others. ${ }^{40}$ The section quoted is specifically targeted on the character of Jeremiah, who is either responsible for or reporting all of the activity within these verses. This activity is described in three parts: 1) a report on the history behind the sacred fire used by Nehemiah at the dedication of the second temple, 2) a prophecy concerning the hiding and promised future revelation of the ark, tent, and altar of incense, and 3) a recollection of the other appearances of sacred fire at the institution of the cult by Moses and the dedication of Solomon's temple.

The second part of these stories about Jeremiah is notable. 2,4-7 indirectly recount an oracle given by the prophet concerning the revelation of the ark, tent of meeting, altar of incense, and God's glory itself at some future point. The prophecy is apparently referenced because the author of the letter hopes it is being realized in his time. This is made clear at the close of the letter, wherein the author makes a final appeal to celebrate the purification festival citing the words of the prophecy $(2,18)$. Here the document appears to be referenced because of its prophetic character. The oracle is cited as a reason for which the Judeans in Egypt should also celebrate the purification. The contemporary events seem to be understood as preparation for the promised ingathering of the people to the temple. According to the letter in 2,17-18, God has been responsible for the rescue of his people as well as their cherished institutions. God has also purified the holy place. For the author, the next logical step is that God will gather his people to the temple and reveal his glory, because he made it known through Jeremiah. The text is referenced to encourage the Egyptian Judeans in realizing this. There is no indication that all the records are considered prophecy. Only this section of the records contains an oracle, and only it is read as a promise to come true in the near future.

By contrast, the report concerning the sacred fire, in 2,1-3, looks backwards. The story provides the context for the sacred fire first mentioned in the anecdote concerning Nehemiah at 1,18-36. It shows that this fire was hidden at the behest of Jeremiah, and that this happened just as he was giving the law to the exiles on their way out of the land. This story provides a histo-

39. E.g. Craig A. Evans, "The Scriptures of Jesus and His Earliest Followers," in Lee Martin McDonald and James A. Sanders (eds), The Canon Debate (Peabody, Mass.: Hendrickson, 2002), 185-195, esp. 188.

40. Schorch, "Libraries," p. 171, hypothesizes that the Jeremiah account might come from a source or sources containing stories about prophets. 
ry for this sacred fire before it came into the possession of Nehemiah. It answers the questions of who saved it, and when. This element is important because this fire is one of the reasons for the feast. In this case the document is offered as the authoritative account of the fire's history.

Similarly, the third part of Jeremiah's activity reported in this source claims that he informed the departing exiles that Moses and Solomon received divine fire when instituting their cults. Solomon is also said to have celebrated the eight day festival that is the purpose of the letter. Here as well the source is relied upon for its historical value. It is not clear whether the sources in question are some version of the accounts in Leviticus 9,24 and 2 Chronicles 7,1-3, though it is significant that these too connect the divine fire with a revelation of the glory of God. ${ }^{41}$ The sacred fire has a history that goes back before Jeremiah to Solomon and even to Moses. The source is being used to show the importance of that fire to the cult, and its special role during periods of transition in the cult. The source is being made to show that the fire, and even a celebration related to it, is actually an institution in Judea's inherited history. The source is thus alleged to be historically significant. There is no indication of why the source might be seen as reliable, but one possibility is its presence in the $\operatorname{archives}^{42}$ or libraries ${ }^{43}$ of Nehemiah and Judas.

Schorch has argued that the term $\beta \imath \beta \lambda_{10} \theta \eta \dot{\kappa} \eta$ should be understood here as an archive, or record office, based on the contents of Nehemiah's $\beta 1 \beta \lambda_{10} \theta \eta \dot{\kappa} \kappa$ as well as usage in Ezra 6,1 and Esther 2,23, where it is clearly used in such a sense. ${ }^{44}$ If indeed the sense is correct, then it would logical that the document would be of historical value. By their nature archives contained official writings of the state and temple. ${ }^{45}$ Though that does not prove their truthfulness, it may be alleged to lend credibility to their contents. This might be especially so, given the nature of the record, which ostensibly reports on a cultic tradition maintained by kings (Solomon) and priests (cf. Jer 1,1 and 2Macc 1,19.33). The work may not even have held sweeping authority for the author of the letter, but was authoritative on this particular matter.

The account of Nehemiah's use of sacred fire upon the dedication of the second temple does not explicitly come from a written document. However, a

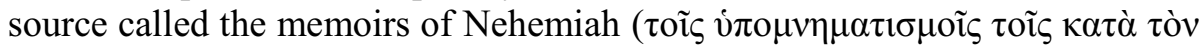

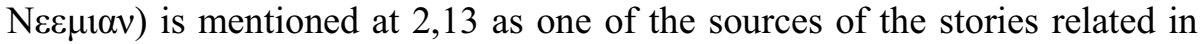
the letter. It seems reasonable to associate the material about Nehemiah in 1,18-36 with this source. The content related in the memoirs essentially gives the history of the feast of the fire. It relates how the fire was found, miraculously ignited on two occasions, and eventually sanctified.

41. Bergren, "Nehemiah," p. 252, has preceded me on this point.

42. Schorch., pp. 173-174.

43. Haran, “Archives,” p. 59; Lange, “2 Maccabees,” p. 166.

44. Schorch, "Libraries," p. 173.

45. Haran, "Archives," pp. 52-53. It should be noted that Haran classifies this collection as a (non-existent) library. 
The anecdote is apparently used to convince the Judeans in Egypt of the worthiness of the festival. Several of its themes are supported by the unnamed source concerning Jeremiah, including the hiding of the fire prior to exile, the connection between the fire and momentous sacrifices, and the link between this festival and gathering the Judean people at the temple. ${ }^{46}$ Nehemiah's memoirs relate an authoritative account of these events. The authority likely arises from Nehemiah's authorship. Because the narrative follows his own experiences and treats events in his own day, it is unlikely that the authenticity can be questioned.

This leaves open the possibility of whether the text is understood to be decisive for action. The tone of the letter would indicates it is not. The Judeans in Egypt are requested to celebrate the purification. The story is supported by other records to show the tradition of the temple fire extends even further into the past. ${ }^{47}$ The possibility of fulfilling the prophecy of God's glory is argued. These are all marshaled to convince the Judeans in Egypt to celebrate, but it is never indicated that the texts require it. The texts are authoritative in narrow spheres: Nehemiah for his own history, the unnamed writing concerning Jeremiah for the story of the fire in more ancient times, and Jeremiah's prophecy for its promise of future events. All of these are combined in an effort to gain acceptance of the festival.

The emergence of these texts (whether actual or inventions of our author is impossible to judge from our historical perspective) as authorities in the context of temple worship may itself derive from older Judean and Yehudite tradition. Watts has argued that the first texts to gain authority were those advocating and governing rituals. ${ }^{48}$ These ostensibly ancient texts would have aided the Jerusalem priesthood in asserting their ritual authority by proving their continuity with tradition, even when the ritual might have been an invention. Such efforts can be seen in 2 Kings 22-23 regarding Passover and Nehemiah 8 with the celebration of Tabernacles. ${ }^{49}$ Though we do not agree with Watts' conclusion that all texts emerged in the ritual context, these texts in 2Maccabees for diverse reasons are asserted as authorities within this context. Even the titles mentioned in 2Macc 2,13-15 may be associated with buttressing the purification festival. Though it is dangerous to guess what the contents of these titles might be, scrolls about kings and prophets and letters of kings concerning votive offerings might easily be understood as containing material pertinent to the purpose of the letter. After all both kings and prophets are mentioned even in the short passages relating Jeremiah's activities. ${ }^{50}$

46. Bergren, "Nehemiah," p. 250, also notes the connection between all of these stories.

47. Ibid., p. 254.

48. James Watts, "Ritual Legitimacy and Scriptural Authority" JBL 124 (2005), pp. 401-417, esp. p. 416.

49. Cf. Watts, "Ritual," pp. 406-407.

50. Schorch, "Libraries," p. 171, makes a similar argument about the books concerning prophets. 
Less can be said about the scrolls of David, but their use in this context is not out of the realm of possibility.

\subsection{The Translator's Prologue of Sirach}

Like the passage from 2Maccabees, the translator's prologue to the Greek version of the book of Sirach has frequently been studied for its input on questions of canon and authority. These center on the three appearances of three categories of literature within the prologue, namely: the law, the prophets/prophecies, and the others/rest. ${ }^{51}$ The primary debate has concerned whether the prologue attests a tripartite canon, indicating the closure of three traditional divisions of the Hebrew Scriptures, or at least part of them. ${ }^{52}$ No consensus has emerged as to how this literature is regarded by the translator, though most would recognize that he accords it some special status. I do not seek here to prove that there is or is not a canon, or even scriptural recognition. I only wish to argue that the translator does recognize these texts as having some authority, and to note for what reasons he recognizes their status.

The first point, that these texts are being recognized for some special status would seem obvious. They are said to have provided the translator and his

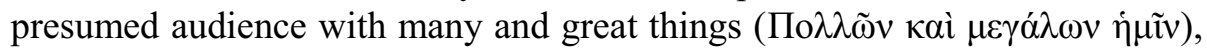
so much so that they necessitate praise for the wisdom and education ( $\pi \alpha 1 \delta \varepsilon i ́ \alpha \varsigma \kappa \alpha i ̀ ~ \sigma o \varphi i ́ \alpha \varsigma)$ of their authors. Moreover, the translator testifies that his ancestor devoted his life to the study of these works (7-10). The quality of these books is so high that even his ancestor's book has a share in their character of wisdom and education. He likely alleges that his ancestor's book deserves to be among them, as is indicated by the similar praise it receives

\section{McDonald, Biblical, p. 83.}

52. The range of arguments is quite broad, and each opinion represented has many subscribers. For a view that a closed canon is depicted in the prologue see Beckwith, "Formation," p. 52. Eugene Ulrich, "Non-Attestation of a Tripartite Canon in 4QMMT," $C B Q 65$ (2003), pp. 202-214, tempers that enthusiasm slightly by recognizing a scriptural category in the law and the prophets, and a non-scriptural category in all the other books. Albert C. Sundberg, "The Septuagint: The Bible of Hellenistic Judaism" in Lee Martin McDonald and James A. Sanders (eds), The Canon Debate, (Peabody, Mass., 2002), pp. 68-90, esp. p. 81, argues that the text proves much of the LXX is already in existence by the time of the translation. Harry M. Orlinsky, "Some Terms in the Prologue to Ben Sira and the Hebrew Canon" JBL 110 (1991), pp. 483490 , suggests that nothing more than the culmination of past wisdom is referenced here, while Armin Lange, "The Law, the Prophets, and the Other Books of the Fathers" (Sir. Prologue) Canonical Lists in Ben Sira and Elsewhere?" in Géza G. Xeravits and József Zsengeller (eds), Studies in the Book of Ben Sira: Papers of the Third International Conference on Deuterocanonical Books, Shime'on Centre, Pápa, Hungary, 18-20 May, 2006 (JSJS, 127; Leiden: Brill, 2008), pp. 55-80, esp. p. 70 regards the terms as referring to the whole of Judean literature. 
and the great effort he spends on translating it for a Greek speaking audience. $^{53}$

It is possible that other works that can be praised along the same lines. Though they are never specifically named, these can be deduced through the author's belief in a seemingly infinite chain of responsibility for passing on teaching through speech and publication (4-6). Even if these derivative writings are understood to become part of these collections of literature after they are written, there is a clear understanding that the number of texts bearing these qualities has the potential to grow exponentially. Since this discussion does not focus on notice of these texts as a proto-canon or as scripture, but upon their recognition as authorities, the evidence is sufficient. These texts are quite clearly alleged to have the power to influence actions, opinions, and beliefs, just as others texts potentially do.

The reasons for which these texts are authorized are twofold. Both of them are intertwined. The law, prophets, and other ancestral books are rewarding (1) and lead to a lawful life (14). We can see that they are rewarding in the first verse of the prologue, where it is said many and great things have been given through the texts. This is reinforced by verse 14 in which lovers of learning are noted to benefit much more through reading these books. The benefit in this verse derives from the texts' ability to guide people in living lawfully. The tendency that the law, the prophets, and the other books, this time explicitly including the translator's own work, lead towards living lawfully is also seen in the final verse of the prologue, where it is argued that they prepare ones character for such a life (36). Living lawfully appears to be a goal to which the translator attaches great value, and these texts have proven successful to attain that goal. Their authority, then, lies in empirical trial. They have been selected on account of their usefulness in leading to a good life.

\section{Conclusions}

As we consider the examples from the $2^{\text {nd }}$ century literature surveyed, we surely notice that there are a great variety of reasons for which a text is understood or alleged to be authoritative. In the Letter of Aristeas, it was recognized that divine origin stands out as the primary reason for the law to be considered authoritative. Any other quality the law has, including purity and philosophical character, all appear to derive from the divine origin of the law. This idea of divine origin does not betray a simplistic fundamentalist understanding of biblical origins wherein the law is dictated to Moses as secretary. It is understood as a divine law that is interpreted by various people given preternatural abilities to understand and explain it to humanity. Since the law

53. Francis Borchardt, "Prologue of Sirach (Ben Sira) and he Question of Canon," in James Charlesworth, Lee Martin McDonald, and Blake A. Jurgens (eds), Sacra Scriptura: How "Non-Canonical" Texts Functioned in Early Judaism and Early Christianity (JCTRS, 20; London: Bloomsbury, 2014), pp. 64-71. See also Carr, Writing, p. 265, who comes to similar conclusions. 
comes through a heavenly source, it is understood to govern all humanity, even kings, and applies in all areas of life.

In the letter prefixed to 2Maccabees, the scope of the texts were far different. The unnamed records that deal with Jeremiah and the sacred fire present at the temple, as well as the memoirs of Nehemiah apply to a very specific situation: the celebration of a festival of purification. These texts are accepted for their historical accuracy due to being ancient official records and memoirs. They are not necessarily alleged to compel the celebration of the festival, they merely testify to the antiquity and propriety of the festival in Judean history. That said, the letter attached to 2Maccabees does not forsake revelation as a reason to recognize a text as authoritative. Jeremiah's pronouncement concerning God's intention to bring together all the people at the holy place is interpreted as prophecy precisely for this reason. However, the memoirs of Nehemiah and the records have no share in that quality, though they are authoritative.

In the prologue to the Wisdom of Ben Sira, neither history nor divine revelation play a role in authorizing the law, the prophecies, and the other writings. It is manifest that these ancestral books (10) are the work of human beings. Some, like the grandson and Ben Sira, are even specified. Instead, it is their success in leading to a lawful life that makes them authoritative. They are empirically observed to accomplish their goal. That is to benefit their readers by giving them a good life, lived lawfully.

These examples show that when considering the concept of authority in ancient Judean literature, we should be ever mindful of authorization as an act of reception. This leads to further conclusions: a text can be authorized for diverse reasons by different readers. Different texts can also be considered authoritative by separate reading communities. Further, texts or even parts of texts might be authoritative in one sphere, but useless in another. As we can see from these $2^{\text {nd }}$ century works, authority has a much wider variety of applications in ancient literature than scholarship has recognized. 